ACTA THERIOLOGICA

Vol. 33, 27: 379-391, 1988

\title{
The Effects of Vegetative Cover on the Community Structure of Prairie Rodents
}

\author{
Burt P. KOTLER ${ }^{1}$, Michael S. GAINES \& Brent J. DANIELSON ${ }^{2}$
}

Kotler B. P., Gaines M. S. \& Danielson B. J., 1988: The effects of vegetative cover on the community structure of prairie rodents. Acta theriol., 33, 27: 379-391. [With 5 Figs]

The effect of vegetative cover on a community of grassland rodents was investigated by mowing and adding hay to experimental grids and monitoring changes in the abundance of the rodent species. After the addition of cover, rodent species diversity peaked and then declined to about 1.5 species. Diversity peaked on the mowed grid one month after it did on the gird with supplemental cover and then declined. Following the addition of cover, densities of prairie voles (Microtus ochrogaster) steadily increased while densities of western harvest mice (Reithrodontomys megalotis) and deermice (Peromyscus maniculatus) declined. Total rodent densities did not change until spring plant growth bagan. Reduction of cover had little effect on the densities of $P$. maniculatus and $R$. megalotis. However, reducing cover initiated a decline in $M$. ochrogaster density which resulted in local extinction from the grid. Differences in food availability and predatory risk due to the cover manipulations may best explain these results.

[University of Kansas, Department of Systematics and Ecology, Lawrence, Kansas 66045, U.S.A.]

\section{INTRODUCTION}

Investigations of the community structure of animals frequently examine the association of the structure of the vegetation with the diversity and population dynamics of animal species. For example, species diversity of both birds and desert rodents is often correlated with foliage height diversity (e.g., MacArthur, 1962; MacArthur \& MacArthur, 1961; MacArthur et al., 1966; Cody, 1974; Rosenzweig $\&$ Winakur, 1969). Also, the relative abundance of genera of desert rodents is determined by vegetative cover (Rosenzweig, 1973; Kotler 1984). Birney et al. (1976) found that a site-dependent threshold level of vegetative cover is necessary for microtine populations to undergo multi-annual cycles. Taitt and co-workers (Taitt et al., 1981; Taitt

${ }^{1}$ Present address of BPK: Ben-Gurion University of the Negev, Jacob Blaustein Institute for Desert Research, Sede Boqer Campous 84 993, Israel.

2 Present address of BJD: University of Georgia, Department of Zoology, Athens, Georgia 30602, U.S.A. 
\& Krebs, 1983) observed that manipulation of cover affected the population dynamics of townsend voles (Microtus townsendi Miller, 1889). Thus the structure of plants at a site affects the structure of the animal community also found there.

Two major ways that vegetative cover could influence community structure of grassland rodents are by providing protection against predation and by providing food. Rose \& Birney (1985) concluded that the greatest importance of vegetative cover in Microtus populations is concealment and protection from predators. The amount of cover should influence which rodents are present in a community (Kotler, 1984). Species which are more vulnerable to predation should be rare or absent in areas of low plant cover, but may be present where cover is more dense. Certain attributes should make some species more prone to predation. For example, animals with large body size are more attractive to predators and suffer higher rates of predation than animals with smaller body size (Kotler et al., 1988). Also, more agile animals are better at evading the attacks of predators (Bartholomew \& Caswell, 1951; Wywialowski, 1987). In the case of rodents in Kansas grasslands, prairie voles (Microtus ochrogaster Bole Moulthrop, 1942) with relatively large body size and bullet-shaped body with short legs should be more vulnerable to predation than the other rodent species in the community; western harvest mice (Reithrodontomys megalotis Baird, 1858) with small body size and good climbing ability should be less vulnerable. Thus, in areas with abundant cover, M. ochrogaster should be common whereas in areas with sparse cover $M$. ochrogaster should be in lower relative abundance compared to $R$. megalotis. Also, overall rodent density should be lower where cover is reduced because of high rates of predation and reduced rodent foraging activity.

Changes in food availability brought about by changes in cover can also affect which rodents are found in a community. For example, Abramsky (1978) added food to a short grass prairie in the form of whole cats and alfalfa pellets. Ord's kangaroo rat, Dipodomys ordii Woodhouse, 1853, invaded the experimental plot and persisted in high numbers in response to this treatment. However, when increased productivity was accompanied by vegetative growth (from the addition of nitrogen and water), D. ordii was excluded and two new species ( $M$. ochrogaster and $R$. megalotis) invaded the plot. These results and those of Taitt and co-workers on the townsend vole, Microtus townsendi (Taitt et al., 1981; Taitt \& Krebs, 1983) suggest an interaction of cover as protection against predators and cover as a source of food in determining rodent species density and community structure. Furthermore, these results suggest that additions of cover will greatly benefit 
Microtus (in this case, $M$. ochrogaster) and reduction of cover will most harm it.

We attempt to corroborate the suggested effects of cover - via its interactions on predator protection and food availability - on the structure of a grassland community of small rodents in eastern Kansas by mowing and by adding hay. The manipulation was continued for $61 / 2$ months during which rodent populations were censused biweekly.

\section{METHODS}

The field work was carried out at the Nelson Environmental Study Area of the University of Kansas located $16 \mathrm{~km}$ NE of Lawrence, Kansas in Jefferson County, Kansas, U.S.A. We established four 0.81 ha live trapping grids (grids A, G, I and $\mathrm{K}$ ) in fields of brome grass (Bromus inermus Leyss.) and prairie vegetation in the autumn of 1983. Grids I and A were $30 \mathrm{~m}$ apart, Grid G was located approximately $100 \mathrm{~m}$ from $\mathrm{I}$ and $\mathrm{A}$, and Grid $\mathrm{K}$ was located approximately $600 \mathrm{~m}$ from I and A. Trap stations were arranged $10 \times 10$. A single Longworth live-trap was placed at each station. We trapped the grids biweekly from late October 1983 (week 232) through early August 1984 (week 273). Data from grids A and G were part of a longer study going on concurrently. During each trapping session, traps were set for two consecutive nights, and during cooler months, (October through mid-May) the intervening day. Traps were locked open between sessions to allow animals to become and remain familiar with traps. Traps contained cotton and were baited with crimped oats. We marked captured animals with ear tags, and recorded species, station, weight, sex and external reproductive characteristics for each captured animal in each trap session.

We manipulated the vegetative cover on the grids as follows. The cover on the most productive grid (highest rodent densities, highest rodent growth rates), grid $\mathrm{K}$, was reduced by mowing. We first mowed grid $\mathrm{K}$ to a height of $20 \mathrm{~cm}$ on 26 January 1984 (week 246) and then again following periods of plant growth: 22 May (week 263), 5 June (week 265) and 19 June 1984 (week 267). Clippings from mowing were left on the grid so as to reduce least the potential food biomass available to herbivorous rodents. On grid I, cover was augmented in the manner of Taitt et al., (1981) and Taitt \& Krebs (1983) by adding hay to the grid. Cover was added on 23 January 1984 in the form of 110 bales of hay spread evenly over the grid. The hay added an average of $16 \mathrm{~cm}$ depth of cover prior to settling. We did not replenish hay in the spring due to increased cover resulting from new plant growth. Both grids were censused for 12 weeks prior to the initiation of the experiments. The experiments were then continued for 26 weeks. Grids $\mathrm{A}$ and $\mathrm{G}$ served as unmanipulated controls.

Limited time and resources prevented replication of the experiment, so it is possible that the observed changes in species composition and density following the application of the experimental treatments were a result solely of natural spatial and temporal fluctuations in rodent densities. We think that our choice of grids for receiving each particular manipulation and the use of unmanipulated control grids made this unlikely. We chose the most productive grid, grid $\mathrm{K}$, for mowing because it was predicted that removal of cover would cause in- 
creased rates of predation and decreased rodent foraging activity and result in a reduction of rodent density and species diversity. Therefore, if rodent densities on grid $\mathrm{K}$ dropped below densities on grids $\mathrm{A}, \mathrm{G}$, and I following the manipulations, the changes were likely to have been due to the experiments. Also, the lack of large changes in relative abundance of rodents on the grids for 4-12 weeks prior to the start of the 26 weeks of manipulations suggest that grid $\mathrm{K}$ was more productive than grid I and that these differences were fairly stable. Nonetheless, because of the lack of replication of each experimental treatment, our results and interpretation are only tentative.

Comparisons of rodent species densities were made using direct enumeration (Krebs, 1966). We use survivorship and trappability data to put $97.5 \%$ confidence intervals on the true population density, with the lower bound being the minimum number alive (MNA, Hilborn et al., 1976). All comparisons of densities and changes in population numbers are based on comparisons of $97.5 \%$ confidence intervals: only when the confidence intervals were non-overlapping would we note a significant difference or change. We computed a confidence interval for each species on each grid each week that trapping data permitted. Confidence intervals on Figs. 2-5 are omitted only for clarity of visual presentation. The following species were present on the grids during the study: Microtus ochrogaster, Synaptomys cooperi Baird 1858, Sigmodon hispidus Say and Ord, 1825, Peromyscus maniculatus Bangs, 1898, Reithrodontomys megalotis, Blarina brevicauda Baird, 1858, and Cryptotis parva Miller, 1912.

\section{RESULTS}

Differences in rodent densities existed on the two experimental grids prior to the start of the manipulations (Fig. 1). Grid $\mathrm{K}$ had a significantly higher overall rodent density, averaging 36.3 individuals in

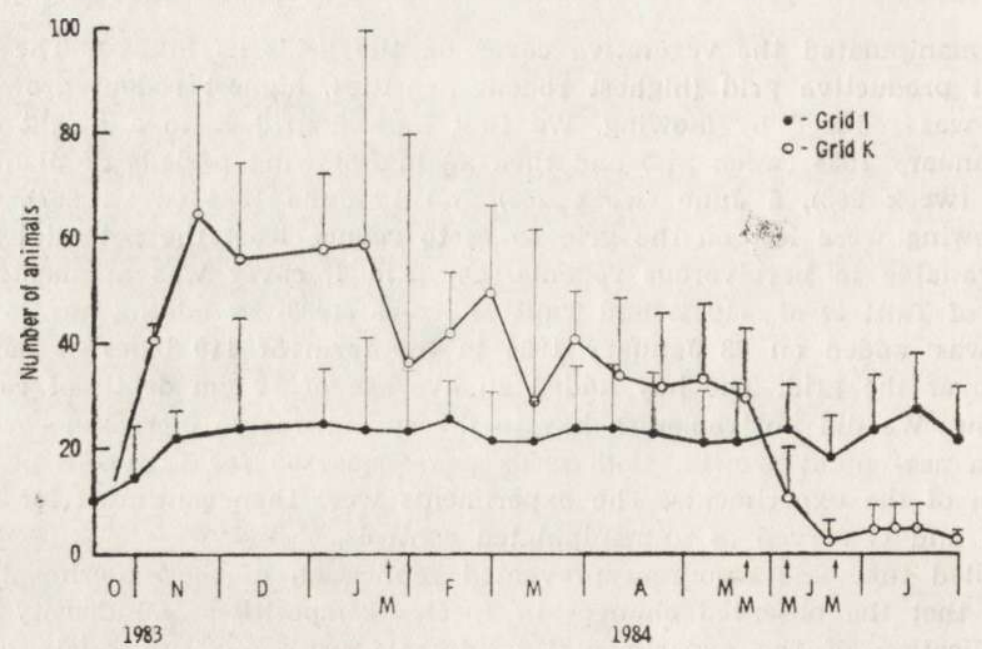

Fig. 1. Total number of rodents on grid I and grid K. Minimum number known alive (MNA) is graphed (plus $97.5 \% \mathrm{CI}$ ) for all species combined for both grids. The arrows with $\mathrm{M}$ refers to when grid $\mathrm{K}$ was mowed. Hay was added to grid I on 23 January 1984. 
the six pre-manipulation census periods compared to 15.3 individuals on grid I. There were also more small mammal species, including insectivores, on grid $\mathrm{K}$ (7 us. 6). The control grids $\mathrm{A}$ and $\mathrm{G}$ were most similar to grid I, and did not differ from I in premanipulation densities. During the experiment, rodents exibited typical population dynamics on the control grids compared to the same grids in previous years (Johnson \& Gaines, 1985).

The two experimental grids showed very different patterns in changes in total density during the study (Fig. 1). Total densities on grid I did not change significantly throughout the experiment and averaged 24 animals. Density on I was generally statistically indistirguishable from the control grids (Fig. 2) with no pattern to the deviation from control grid $\mathrm{G}$ and a slightly higher density on I relative to
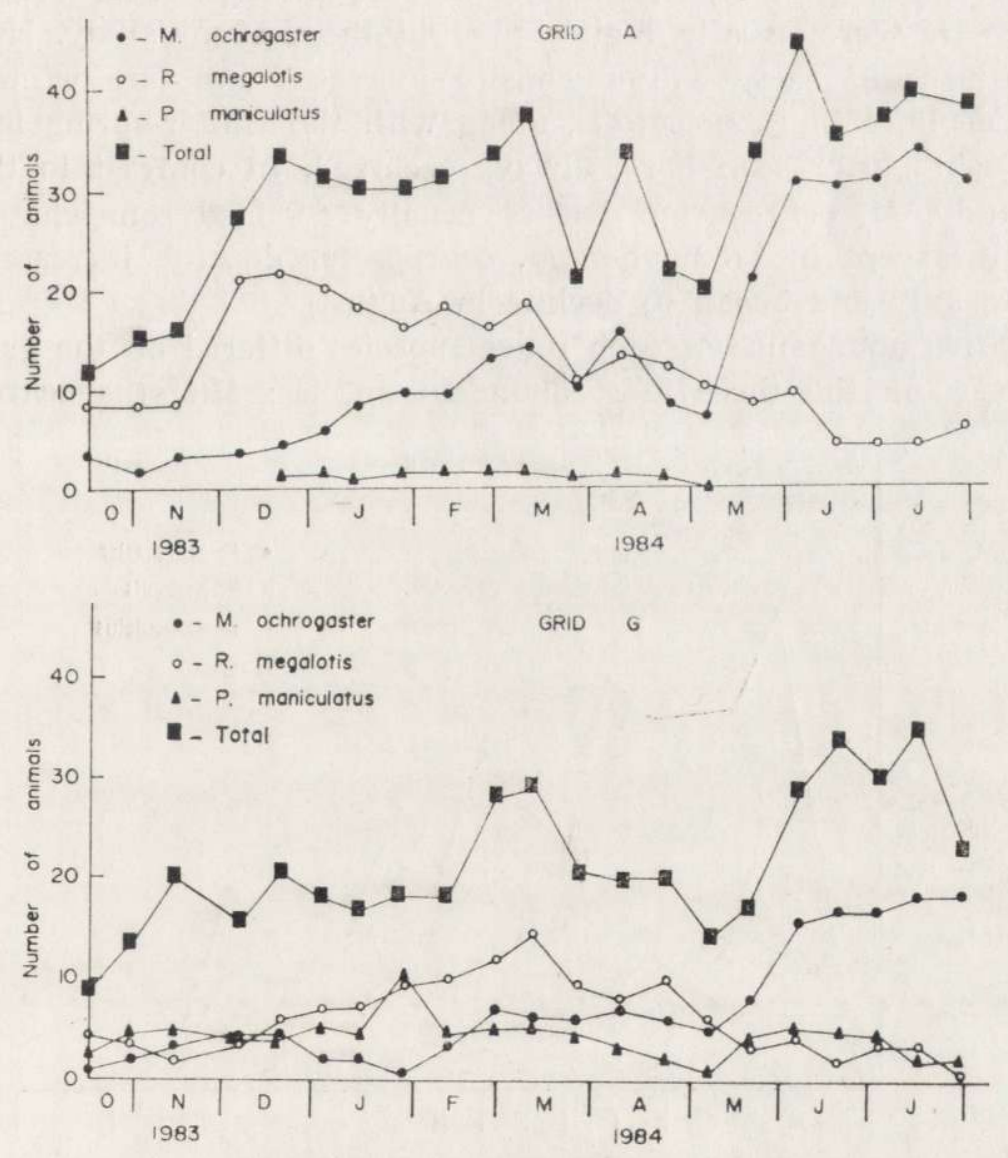

Fig. 2. Total number of rodents and number of individuals of three species on the control grids, $\mathrm{A}$ and $\mathrm{G}$. 
control grid A in the last few weeks of the experiment. Density on grid $\mathrm{K}$ changed considerably. Prior to the habitat manipulation, densities on grid $\mathrm{K}$ were higher than on the other grids. Following the first mowing on grid $\mathrm{K}$, density declined and by mid-April was statistically indistinguishable from that on grid I. Following the resumption of mowing in the spring (late May), densities on grid $\mathrm{K}$ plunged and were significantly lower than on grids. A, G or I by early June. Thus, the results of habitat manipulations support our predictions with respect to overall abundance; reduced cover resulted in lower population densities.

The densities of $M$. ochrogaster and $R$. megalotis recorded on the control grids A and I during this study are typical for these populations. Johnson \& Gaines $(1985,1988)$ studied the demorgaphy of these two species on grids A, G, and I from 1979 through 1982. Densities in those years were usually higher than in the current study. However, the patterns of early winter density increases and late winter/early spring declines in $R$. megalotis, along with the winter-spring increases in $M$. ochrogaster seen here, always occurred. In contrast to the current study, $M$. ochrogaster density usually declined somewhat in the summer (except in 1982 when $M$. ochrogaster density increased from April to July and began to decline in August).

Relative abundance of each rodent species differed on the grids. We will focus on the three most abundant species: Microtus ochrogaster,

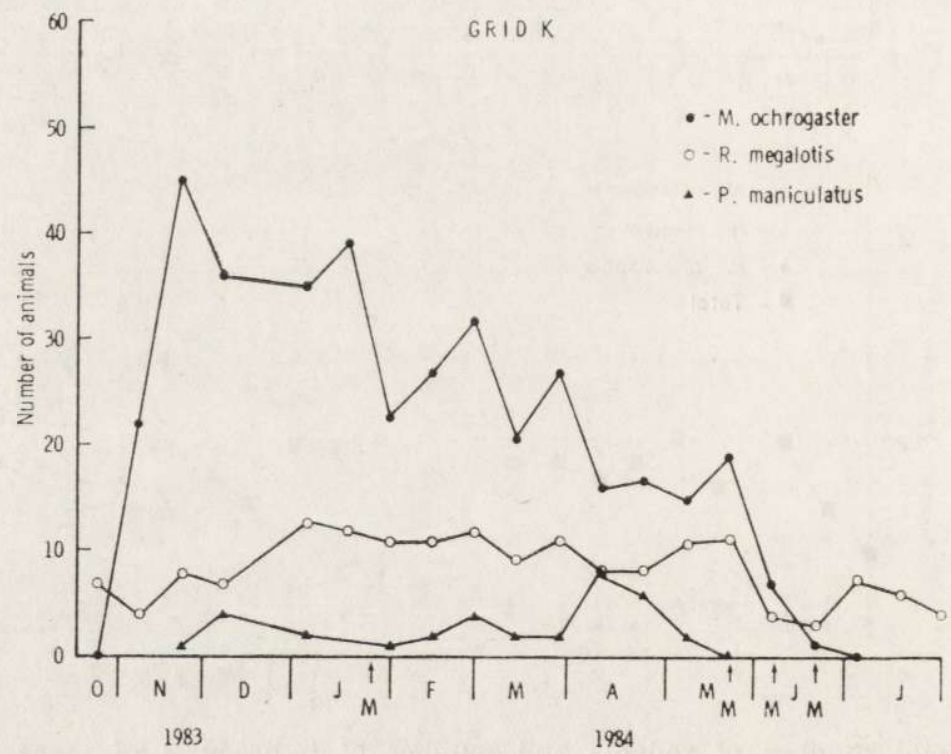

Fig. 3. Numbers of individuals of three species on grid K. Arrows with M refer to dates when grid $\mathrm{K}$ was mowed. 
a herbivore and Reithrodontomys megalotis and Peromyscus maniculatus, both omnivores. On grid $\mathrm{K}, M$. ochrogaster was the most common species, averaging 28.4 individuals, excluding the first census. $R$. megalotis had much lower densities, averaging 4.7 individuals on the grid in the six census periods. P. maniculatus was present for at least four of the six census periods, but had four or less individuals (Fig. 3). $M$. ochrogaster density declined from 39 in mid-January just prior to the first mowing, to 16 in mid-April. The population resumed its decline starting in late May (coinciding with renewed mowing to keep cover low), and ending with local extinction in late June. During this period, $M$. ochrogaster populations on the control grids increased. In fact, the $M$. ochrogaster population has been monitored on control grid A since 1979 (Johnsonn \& Gaines, 1985), and in contrast to M. ochrogaster on the mowed grid, has never become even temporarily extinct. Density of $M$. ochrogaster on $\mathrm{K}$ was significantly higher than on the control grids until the resumption of mowing when it then declined below $M$. ochrogaster density on the controls (Fig. 2). Reithrodontomys megalotis was little affected by mowing although in late May its density also declined. Spring declines in $R$. megalotis densities were

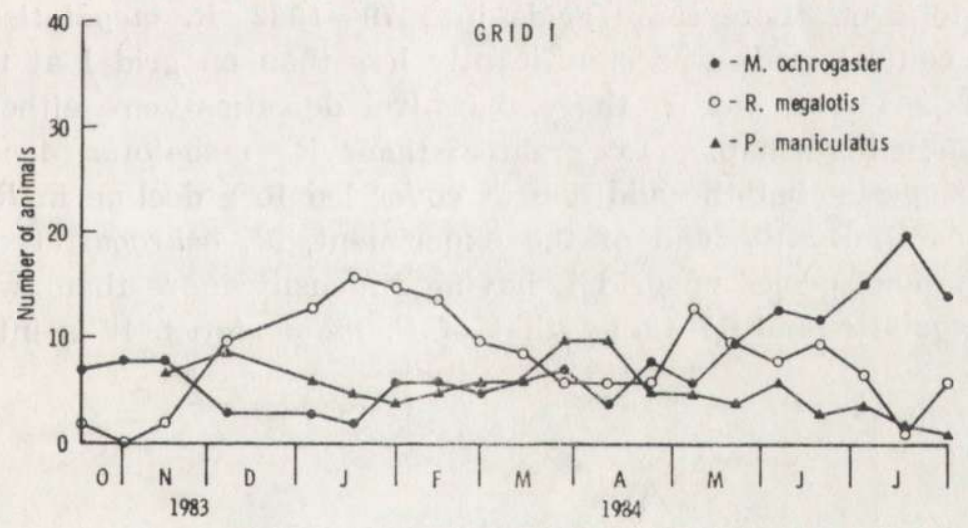

Fig. 4. Numbers of individuals of three species on grid I. Hay was added to the grid on 23 January 1984.

typically seen on control grid A prior to these experiments in 19741982 (Johnson \& Gaines, 1988). By early August, only individuals of $R$. megalotis remained on the grid. $R$. megalotis density was lower on $\mathrm{K}$ than on control grid $\mathrm{G}$ throughout the experiment, but was higher on $\mathrm{K}$ than on control grid A until the last few weeks, when density on A may have been higher (Fig. 2). An effect of mowing on R. megalotis cannot be ruled out entirely, but at best the effect was slight. $P$. maniculatus increased from the time of initial mowing until the 
end of March; by May it had disappeared from the grid. P. maniculatus persisted until the end of the experiment on only one of the two control grids (Fig. 2), making conclusions regarding the effect of the treatment on this species hard to draw.

On grid I, R. megalotis was the most common species and $M$. ochrogaster the least common at the onset of the manipulations in January 1984 (Fig. 4). Microtus ochrogaster changed little in density from January 1984 until early May when it increased significantly through mid-July (Fig. 4). The period of rapid population growth of this species coincided with the most rapid growth of vegetation. At the start of the experiment, densities of $M$. ochrogaster on both controls were lower than on grid I. Be the end, control densities were either statistically indistinguishable from or greater than density on I (Fig. 2), suggesting that density changes were not due to the experimental addition of cover (but still may have been a result of vegetation growth). Concomitant with the increase in vole density on grid I was a decrease in density of $R$. megalotis and $P$. maniculatus, a pattern suggestive of interspecific competition. Johnson \& Gaines (1988) also noted and apparent affect of $M$. ochrogaster density on reproductive parameters of $R$. megalotis on these same grids in 1979-1982. R. megalotis density on both control grids was significantly less than on grid I at the start of the experiment, but by the end control densities were either statistically indistinguishable or greater than $R$. megalotis density on I. This suggests that the addition of cover led to a decline in $R$. megalotis density. By the end of the experiment, $M$. ochrogaster was the most common species on grid I, having a density more than twice that of $R$. megalotis and 17 times that of $P$. maniculatus. It is interesting

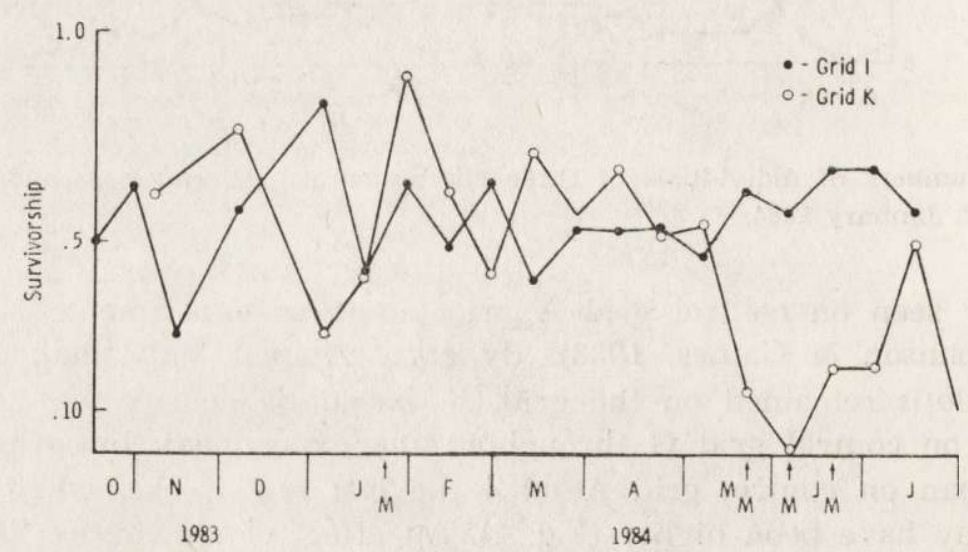

Fig. 5. Survivorship for all species combined on grids I and K. Arrows with $M$ refer to when grid $\mathrm{K}$ was mowed. Hay was added to grid I on 23 January 1984. 
that during the winter period when added cover should have had the biggest effect by adding insulation or reducing predation, there was little change in species density with the exception of a decline in $R$. megalotis density (recall that cover was not added until 23 January 1984). Since the greatest density changes in $M$. ochrogaster occurred during the spring and summer when there was rapid plant growth, we concluded that this species on grid I appears to be affected more by food than by cover per se.

Despite the divergent changes in the rodent communities on the experimental grids in regards to actual species composition, 14 day survivorship on the two grids was similar until late May (Fig. 5). Before then, survivorship for all species fluctuated around 0.5. Following the start of summer mowing, survivorship on grid $\mathrm{K}$ declined sharply and then rose as $R$. megalotis dominated the grid, while on grid I survivorship did not change appreciably through the summer.

\section{DISCUSSION}

Our experiments indicate that density and species composition of grassland rodents respond to changes in cover, but the specific reason for the response is unclear. Consider the experiment in which cover was augmented with added hay on grid I. Following the manipulations prairie vole densities increased while densities of deer mice and harvest mice eventually declined. However, these changes did not take place until substantial spring growth of plants on the grid had occurred, and a similar vole increase also occurred on the control grids. These observations suggest that added cover in the form of hay had little or no effect on vole populations, but cover consisting of highly palatable food such as forbs and grass shoots does have an effect. However, the decline in density of rodents on mowed grid $\mathrm{K}$ may not be attributed to a decrease in food availabillity. After each mowing, all clippings were left on the grid which kept the total plant biomass before and after the manipulation the same. Mowing may actually stimulate growth in plants, particularly grasses (e.g., McNaughton, 1983). Since young shoots are highly palatable (e.g., Van Soest, 1982), food availability may actually have increased on grid $\mathrm{K}$. Yet rodent densities declined (Fig. 1), and two species disappeared entirely from the grid by the end of the experiment (Fig. 4).

Predation could also be responsible for observed density changes on grid $\mathrm{K}$. If the major effect of reducing cover on grid $\mathrm{K}$ is to increase the risk of predation, we would expect the species most susceptible to predation to suffer most from the manipulation (Brown et al., 1988). 
Prairie voles are large in comparison to the other rodents in the community, which should make them attractive to predators (Kotler et al., 1988). Also, the bullet-shaped bodies and short legs of prairie voles make them more susceptible to predation (Wywialowski, 1987) because they are slow and clumsy. Hence, increasing predatory risk by reducing cover should lead to a greater decrease in vole density than in deer mouse or harvest mouse density, which was observed on grid K. Getz (1970) also concluded that a decline in numbers of $M$. pennsylvanicus following mowing and baling of vegetation could be attributed to heavy predation, and Henttonen (1987) concluded that the social system of Microtus makes them especially susceptible to weasel predation.

Another way that reduced cover could have produced density changes on grid $\mathrm{K}$ is through reduced insulation. This would lead to colder winter and hotter summer surface temperatures as well as to greater summer dessication. The predicted result would be a decline of the density of smaller species with less favorable surface-to-volume ratios in the winter due to cold stress and a decline of species not well adapted to moisture stress in the summer. Getz (1971) found that areas of sparse cover may not be utilized by $M$. pennsylvanicus because of higher temperatures there. This insulation hypothesis is unlikely since the density of the smallest species, $R$. megalotis, remained constant following winter mowing while densities of the largest species, M. ochrogaster, steadily declined throughout the experiment (Fig. 3).

We cannot dismiss the possibility that the mowing itself caused substantial mortality, and directly led to the population decline. However, we think this is unlikely for two reasons. First, survivorship on grid $\mathrm{K}$ did not fall following the first mowing in January 1984 (Fig. 5), and the rodent population continued to decline through a four-month period without any additional mowing (Fig. 1). This pattern of density change indicates that the spring decline on grid $\mathrm{K}$ was not due to a single, catastrophic event. Second, mowing was done in the mid-afternoon when rodents were the least active and probably in their burrows.

Several investigators have manipulated cover to examine the effects of predation and food availability on small mammal populations. During a spring decline in numbers in 1979, Taitt et al. (1981) supplied Microtus townsendii with extra cover using hay, and extra food in the form of laboratory chow and whole oats. On the area with extra cover, the rate of decline was significantly lower in males, and females actually increased in numbers compared with the control population. On the area with extra food, the rates of decline of males, and females were lower than the control population, but differences were not 
statistically significant. Taitt et al. (1981) concluded that extra cover reduced predation and that predation may be the driving variable in the spring decline. In another experiment, in addition to adding cover and food, Taitt \& Krebs (1983) covered an area with fish netting to further reduce the amount of avian predation. Taitt \& Krebs (1983) used six different treatment grids (control, net, reduced cover, netcover, net+cower, net+cover +food) and found that male and female density declined on all grids except the net+cover+food treatment. These results suggest that food availability and predation interact in determining Microtus density.

Abramsky and co-workers (Abramsky, 1978; Abramsky et al., 1979) demonstrated more clearly an interaction between food and cover in a grassland community of small mammals. They increased productivity on a shortgrass prairie in two ways. They supplemented food (alfalfa pellets and oats), and they added water, nitrogen, or both. Adding food alone had no effect on the species normally inhabiting the control grids (deer mouse, P. maniculatus; southern grasshopper mouse, Onychomys leucogaster Baird, 1858; and thirteen lined ground squirrel, Spermophilus tridecemlineatus Allen, 1877). Also, adding water alone or nitrogen alone had little effect. However, adding nitrogen and water together resulted in a near tripling of plant biomass, yielding both adequate food and cover from predators. This resulted in the establishment of dense populations of prairie voles and harvest mice and the decline in the densities of $P$. maniculatus, $O$. leucogaster, and $S$. tridecemlineatus. The lack of a response by prairie voles to just food addition in a community where cover from predators is in short supply emphasizes the interaction of food and cover. Their results parallel ours closely, particularly in regards to the response to $M$. ochrogaster to changes in cover.

Taken together, our experimental results from grids $\mathrm{I}$ and $\mathrm{K}$ also suggest that density changes in grassland rodents brought about by changes in cover are due to the interaction of changes in predatory risk and changes in food availability. Increasing food will favor voles, providing predatory risk is sufficiently low. This apparently occurred on unmowed grids at the beginning of the vegetative growing season. Conversely, increasing predatory risk will favor other smaller, more agile species, such as harvest mice and deer mice, better able at escaping attacks as occurred on grid $\mathrm{K}$ after mowing. Our results corroborate those of Getz, Taitt, and Abramsky and suggest that the different ways which cover affects risk of predation and access to food in different rodent species helps determine the structure of grassland rodent communities. 
Acknowledgements: We are grateful to L. Coe, J. Foster, L.D. Gaines, H.B. Gaines, J.F. Jessica, M. Johnson, C.F. Mishka and C. Sagrillo for providing assistance with the field work. W.A. Mitchel provided useful comments on the manuscript. $\mathrm{BPK}$ is a Bat-Sheva de Rothschild Fellow.

\section{REFERENCES}

1. Abramsky Z., 1978: Small mammal community ecology: changes in species diversity in response to manipulated productivity. Oecologia, 34: 113-123.

2. Abramsky Z., Dyer M.I. \& Harrison P.D., 1979: Competition among small mammals in experimentally perturbed areas of the shortgrass prairie. Eco$\log y, 60: 530-536$.

3. Bartholomew G.A., Jr. \& Caswell H.H., Jr., 1951: Locomotion in Kangaroo rats and its adaptive significance. J. Mammal., 32: 155-169.

4. Birney E.C., Grant W.E. \& Baird D.D., 1976: Importance of vegetative cover to cycles of Microtus populations. Ecology, 57: 1043-1051.

5. Brown J.S., Kotler B.P., Smith R.J. \& Wirtz W.O., 1988: The effects of owl predation on the foraging behavior of heteromyid rodents. Oecologia, 76: 408-418.

6. Cody M.L., 1974: Competition and the structure of bird communities. Princeton University Press, Princeton, New Jersey. $1-318$.

7. Getz L.L., 1970: Influence of vegetation on the local distribution of the meadow vole in southern Wisconsin. Occas. Papers Univ. Connecticut, Biol. Sci. Ser., 1: 213-241.

8. Getz L.L., 1971: Microclimate, vegetative cover, and local distribution of the meadow vole. Trans. Illinois State Acad. Sci., 64: 9-21.

9. Henttonen H., 1987: The impact of spacing behavior in microtine rodents on the dynamics of least weasels Mustela nivalis - a hypothesis. Oikos, 50: $366-370$.

10. Hilborn R., Redfield JA. \& Krebs C.J., 1976: On the reliability of enumeration for mark and recapture census of voles. Can. J. Zool., 54: 1019-1024.

11. Johnson M.L. \& Gaines M.S., 1985: Selective basis for emigration of the prairie vole, Microtus ochrogaster: open field experiment. J. Anim. Ecol., 54: $399-410$.

12. Johnson M.L. \& Gaines M.S., 1988: Demography of the Western Harvest mouse, Reithrodontomys megalotis, in Eastern Kansas. Oecologia, 75: 405-411.

13. Kotler B.P., 1984: Risk of predation and the structure of desert rodent communities. Ecology, 65: 689-701.

14. Kotler B.P., Brown J.S., Smith R.J. \& Wirtz W.O., 1988: The effects of morphology and body size on rates of owl predation on desert rodents. Oikos, 53: $145-152$.

15. Krebs C.J., 1966: Demographic changes in fluctuating populations of Microtus californicus. Ecol. Monog., 36: 239-273.

16. MacArthur R.H., 1962: On bird species diversity. II. Prediction of bird censuses from habitat measurements. Amer. Natur., 96: 167-174.

17. MacArthur R.H., \& MacArthur J.W. 1961: On bird species diversity. Ecology, 42: $594-598$.

18. MacArthur R.H., Recher H. \& Cody M., 1966: On the relationship between habitat selection and species diversity. Amer. Natur., 100: 319-332.

19. McNaughton S.J., 1983: Compensatory plant growth as a response to herbivory. Oikos, 40: 329-336. 
20. Pielou E.C., 1975: Ecological diversity. Wiley Press, New York. 1-165.

21. Rose R.K., \& Birney E.C., 1985: Community Ecology [In: "Biology of New World Microtus", R.H. Tamarin, ed]. 310-339. Special Publication No. 8, The American Society of Mammalogists.

22. Rosenzweig M.L., 1973: Habitat selection experiments with a pair of coexisting heteromyid rodent species. Ecology, 54: 111-117.

23. Rosenzweig M.L. \& Winakur J., 1969: Population ecology of desert rodent communities: habitat and environmental complexity. Ecology, 50: 558-572.

24. Taitt M.J., Gipps J.H.W., Krebs C.J. \& Dundjerski Z., 1981: The effect of extra food and cover on declining populations of Microtus townsendii. Can. J. Zool., 59: 1593-1599.

25. Taitt M.J. \& Krebs C.J., 1983: Predation, cover, and food manipulations during a spring decline of Microtus townsendii. J. Animal Ecol., 52: 837-848.

26. Van Soest P.J., 1982: Nutrition ecology of the ruminant. O \& B Books. Corvallis, Oregon. $1-374$.

27. Wywialowski A.P., 1987: Habitat structure and predators: choices and consequences for rodent habitat specialists and generalists. Oecologia, 72: 39-45.

Received 4 January 1988, Accepted 13 June 1988.

Burt P. KOTLER, Micnael S. GAINES i Brent J. DANIELSON

\section{WPEYW POKRYWY ROSLINNEJ NA SKEAD ZESPOEU GRYZONI PRERIOWYCH}

\section{Streszczenie}

Wpływ pokrywy roślinnej na zespół gryzoni preriowych badano poprzez koszenie lub dokładanie siana na powierzchniach odłownych oraz śledzenie zmian liczebności poszczególnych gatunków gryzoni. Na powierzchni ze zwiększoną pokrywą roślinną zróżnicowanie gatunków w zespole gryzoni osiągnęło maksimum, po czym spadło. Zróżnicowanie gatunkowe na powierzchni koszonej osiągnęło szczyt o miesiąc później niż na powierzchni ze zwiększoną pokrywą roślinną i też spadło.

Po zwiększeniu pokrywy roślinnej zagęszczenie Microtus ochrogaster (Wagner, 1842) wzrastało, podczas gdy Reithrodontomys megalotis (Baird, 1858) oraz $\mathrm{Pe}$ romyscus maniculatus (Wagner, 1845) spadało (Ryc. 4). Sumaryczne zagęszczenia gryzoni nie zmieniały się dopóki nie rozpoczął się wzrost roślinności na wiosnę. Zredukowanie pokrywy roślinnej miało mały wpływ na zagęszczenia $P$. maniculatus i $R$. megalotis, ale zapoczątkowało spadek zagęszczenla $M$. ochrogaster, co zakończyło się zniknięciem tego gatunku z powierzchni eksperymentalnej (Ryc. 3). Różnice w dostępności pokarmu id niebezpieczeństwie drapieżnictwa wraz ze zmianami pokrywy roślinnej mogą w najlepszym stopniu tłumaczyć otrzymane wyniki. 